\title{
Efficient Production of Bioactive Insulin from Human Epidermal Keratinocytes and Tissue-Engineered Skin Substitutes: Implications for Treatment of Diabetes
}

\author{
PEDRO LEI, ${ }^{1}$ ADEBIMPE OGUNADE, ${ }^{1}$ KEITH L. KIRKWOOD, ${ }^{2}$ \\ SUZANNE G. LAYCHOCK, ${ }^{3}$ and STELIOS T. ANDREADIS ${ }^{1}$
}

\begin{abstract}
Despite many years of research, daily insulin injections remain the gold standard for diabetes treatment. Gene therapy may provide an alternative strategy by imparting the ability to secrete insulin from an ectopic site. The epidermis is a self-renewing tissue that is easily accessible and can provide large numbers of autologous cells to generate insulin-secreting skin substitutes. Here we used a recombinant retrovirus to modify human epidermal keratinocytes with a gene encoding for human proinsulin containing the furin recognition sequences at the A-C and B-C junctions. Keratinocytes were able to process proinsulin and secrete active insulin that promoted glucose uptake. Primary epidermal cells produced higher amounts of insulin than cell lines, suggesting that insulin secretion may depend on the physiological state of the producer cells. Modified cells maintained the ability to stratify into 3-dimensional skin equivalents that expressed insulin at the basal and suprabasal layers. Modifications at the furin recognition sites did not improve proinsulin processing, but a single amino acid substitution in the proinsulin $B$ chain enhanced $C$ peptide secretion from cultured cells and bioengineered skin substitutes 10- and 28-fold, respectively. These results suggest that gene-modified bioengineered skin may provide an alternative means of insulin delivery for treatment of diabetes.
\end{abstract}

\section{INTRODUCTION}

D IABETES MELLITUS is a group of diseases characterized by an absolute or relative insulin deficiency and poor glucose control (hyperglycemia) in the blood. In type 1 diabetes, also known as insulin-dependent diabetes mellitus (IDDM) or juvenile-onset diabetes mellitus, there is an absolute lack of insulin due to the progressive loss of pancreatic $\beta$-cells in the islets of Langerhans. Destruction of pancreatic islet $\beta$-cells is governed in part by hereditary ${ }^{1}$ and environmental factors such as viruses, toxins, dietary proteins, and stress. ${ }^{2}$ In type 2 diabetes, insulin is present, but the signal for proper glucose uptake is lost because of nutri- tional or genetic factors. ${ }^{3}$ Despite intense research efforts, daily insulin injections remain the gold standard for diabetes treatment, although the discomfort to patients may be significant. On the other hand, islet transplantation suffers from scarcity of donors, the need for long-term immunosuppression, and short-term survival of transplanted cells because of recurrence of anti-islet cell autoimmunity. ${ }^{4,5}$ Therefore, engineering alternative routes of physiologic insulin delivery is a major goal of diabetes research.

Because type 1 diabetes results from lack of insulin production in the pancreas, it is reasonable to assume that secretion of insulin from ectopic sites might overcome the insulin deficit. Several cell types have been used to produce

\footnotetext{
${ }^{1}$ Bioengineering Laboratory, Department of Chemical and Biological Engineering, University at Buffalo, The State University of New York, Amherst, New York; ${ }^{2}$ Department of Periodontics and Oral Medicine, University of Michigan, Ann Arbor, Michigan; ${ }^{3}$ Department of Pharmacology and Toxicology, University of Buffalo, The State University of New York, Amherst, New York.
} 
surrogate $\beta$-cells using gene therapy approaches. Neuroendocrine cells have been proposed as candidates for glucoseresponsive insulin secretion because, like $\beta$-cells, they have active constitutive and regulated secretory pathways and express proprotein convertases $\mathrm{PC} 2$ and $\mathrm{PC} 1 / 3$ that are required for proinsulin processing. ${ }^{6}$ A major drawback of neuroendocrine cells is that other hormones that are co-secreted with insulin may have adverse side effects. ${ }^{7}$ The common ancestry of liver and pancreas - both arise from the gut endoderm during embryogenesis - and the biochemical functions of hepatocytes in glucose homeostasis and ketogenesis have spurred interest in redirecting the fate of cells in the adult liver to function as insulin-secreting pancreatic $\beta$-cells. ${ }^{8,9}$ Transfer of genes that regulate insulin expression such as Pdx1, neurogenic differentiation-1 (Neurod1) and betacellulin (a member of the epidermal growth factor receptor family) afforded $\beta$-cell phenotype to liver cells and reversed streptozotocin (STZ)-induced diabetes in vivo. ${ }^{10-12}$ However, adverse effects have also been observed, with expression of Pdx 1 for 4 weeks resulting in death of the C57BL/6 mice, possibly due to co-expression of trypsin, a digestive enzyme that is also regulated by $\mathrm{Pdx} 1 .^{12}$ Other surrogate targets that have been proposed for insulin delivery include intestinal cells ${ }^{13}$ and dermal fibroblasts. ${ }^{14,15}$

In contrast to tissues such as those in the pituitary gland or liver, the skin is easily accessible, facilitating isolation of epidermal cells from the patient. Epidermal keratinocytes can be easily expanded in culture, genetically modified, and used to prepare 3-dimensional (3D) skin equivalents. Use of autologous cells obviates the need for immuno-isolation devices or immunosuppressive drugs during transplantation of engineered tissues. Accessibility also allows for the removal of transplanted tissue if adverse effects occur. Finally, genetically modified epidermal cells have been shown to secrete large amounts of proteins that reach the systemic circulation via capillaries (molecular weight $<16 \mathrm{kD}$ ) or via the lymphatic return system (molecular weight $>16 \mathrm{kD}) .^{16-20}$ These advantages make skin an ideal organ for ectopic gene delivery.

Recent studies have provided strong evidence of the feasibility and effectiveness of cutaneous gene therapy. The first study demonstrated partial correction of hemophilia A after grafting factor VIII-deficient mice with skin from factor VIII--expressing transgenic animals. ${ }^{21}$ The second study employed retroviral gene transfer of the leptin gene into human keratinocytes to examine the effectiveness of gene therapy for obesity, diabetes, and infertility associated with leptin deficiency. Tissue-engineered skin with genetically modified keratinocytes was grafted onto transgenic obese $(o b / o b)$ mice, resulting in significant weight reduction and reversal of the obese phenotype. ${ }^{22}$ Skin grafts constituting less than $10 \%$ of the body surface area were sufficient for the correction of leptin deficiency. Finally, a recent study indicated that epidermal cells can efficiently secrete large antibody molecules $(150 \mathrm{kDa})$, which can then enter the systemic circulation. ${ }^{23}$ Collectively, these studies suggest that cutaneous gene therapy may be an efficient clinical modality for the treatment of systemic disorders.

In this study, we modified human epidermal keratinocytes with a gene encoding for wild-type (hppI1) or furin-cleavable (hppI4) proinsulin. We showed that keratinocytes can process proinsulin with furin cleavage sites into mature insulin. Insulin-secreting keratinocytes retained the ability to develop into a stratified epithelium with basal, suprabasal, granular, and cornified layers and to secrete biologically active insulin. To further improve insulin production, we introduced several modifications at the furin cleavage sites and the B chain of proinsulin. Additional arginine residues in the furin recognition sites did not improve processing of proinsulin. However, a single point mutation in the B chain enhanced insulin production significantly, reaching levels as high as $140 \mathrm{pmol} /$ $\mathrm{cm}^{2}$ of bioengineered skin tissue per day. These data suggest that genetically engineered skin may provide an alternative means of delivering insulin for treatment of diabetes.

\section{MATERIALS AND METHODS}

\section{Retrovirus production and cell culture}

The retroviral plasmid BMNIG was kindly provided by Dr. Gary Nolan (Stanford University, CA). From $5^{\prime}$ to $3^{\prime}$, this vector contains the $5^{\prime}$ viral long terminal repeat (LTR), the retroviral packaging sequence $(\Psi)$, a multiple cloning site (MCS), and the internal ribosomal entry site (IRES) sequence, followed by the green fluorescent protein (GFP) and the $3^{\prime}$ viral LTR. Wild-type proinsulin (hppII) and furin-cleavable proinsulin (hppI4) genes were kindly provided by Dr. Docherty (University of Aberdeen, $\mathrm{UK}^{24}$ ). For cloning, hppII and hppI4 were digested using SalI and NotI and ligated into the XhoI and NotI sites of the multiple cloning site of pBMNIG (Fig. 1A). To produce amphotropic retrovirus, human kidney epithelial cell-derived packaging cells (Phoenix-ampho; provided by Dr. G. Nolan) were plated in tissue culture flasks $\left(2.5 \times 10^{4} \mathrm{cells} / \mathrm{cm}^{2}\right)$ and incubated overnight. The next day, retroviral plasmids $(1 \mu \mathrm{g}$ per $2.5 \times 10^{5}$ cells) and FuGENE 6 (Roche, Indianapolis, IN) were mixed $(1 \mu \mathrm{g}: 3 \mu \mathrm{L})$ in $100 \mu \mathrm{L}$ of Dulbeccos' modified Eagle medium (DMEM; Gibco BRL, Grand Island, NY) without serum or antibiotics. The mixture was incubated at room temperature for 15 to $45 \mathrm{~min}$ and then added to the culture medium of packaging cells. The next day (18-24 h later), the culture medium was replenished, and retrovirus was harvested twice at 24 and $48 \mathrm{~h}$ after medium exchange.

Phoenix-ampho cells were cultured in DMEM supplemented with $10 \%$ heat-inactivated bovine serum (Clontech, Logan, UT) and $100 \mathrm{U}$ of penicillin and $100 \mu \mathrm{g} / \mathrm{mL}$ streptomycin (P/S; Gibco BRL), at $37^{\circ} \mathrm{C}$ with $10 \%$ carbon dioxide $\left(\mathrm{CO}_{2}\right)$. Mouse pre-adipocytes (3T3-L1) were kindly provided by Dr. Kyongbum Lee (Tufts University, Medford, MA) and cultured in DMEM plus $1 \% \mathrm{P} / \mathrm{S}$ plus $10 \%$ bovine serum (Gibco BRL) at $37^{\circ} \mathrm{C}$ and $10 \% \mathrm{CO}_{2}$ within 15 passages. To induce differentiation into adipocytes, pre- 


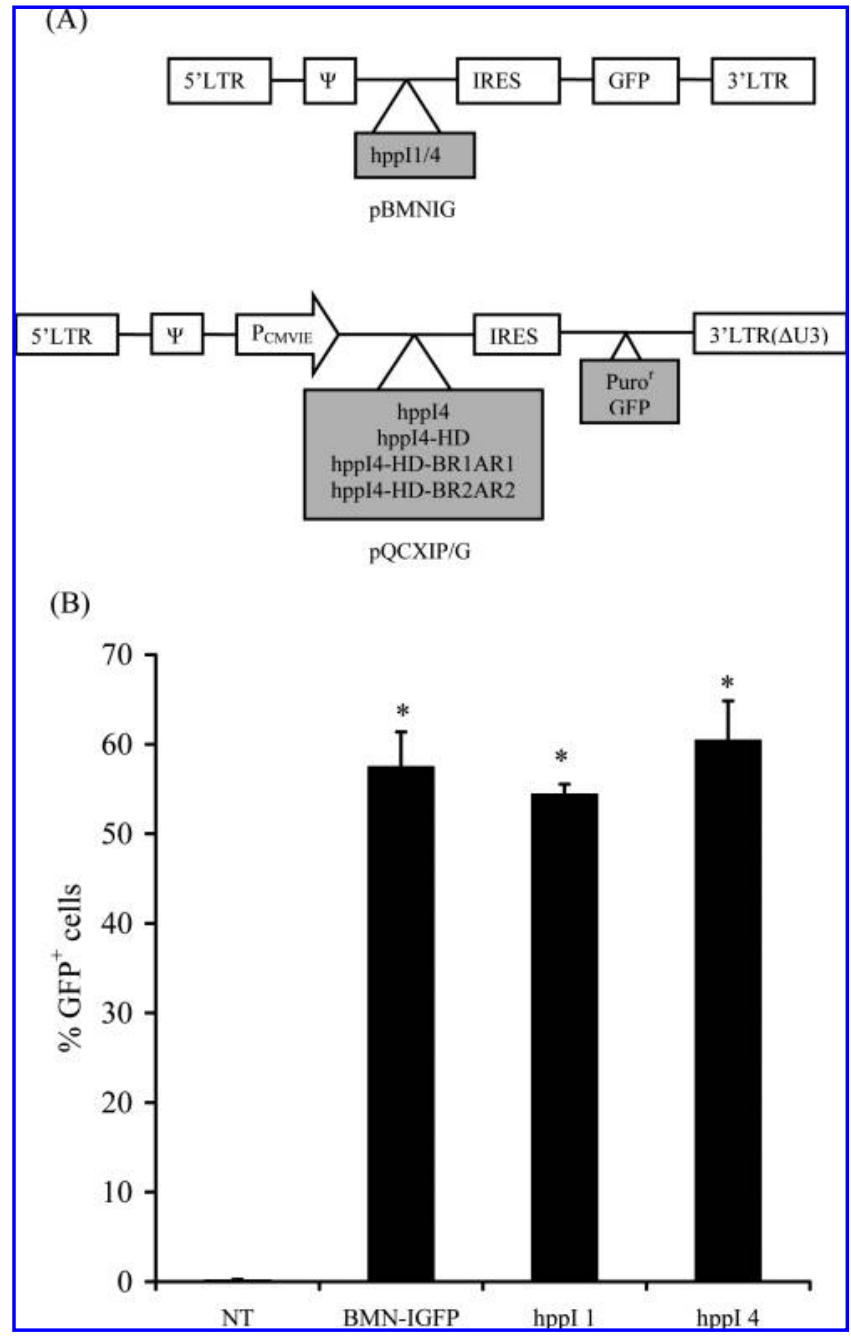

FIG. 1. Efficient transduction of human keratinocytes on recombinant fibronectin with recombinant retrovirus encoding for human proinsulin. (A) Schematics of retroviral plasmids used in this study. (B) Human keratinocytes $\left(12,500\right.$ cells $\left./ \mathrm{cm}^{2}\right)$ were transduced with retrovirus encoding for wild-type proinsulin (hppI1), furin-cleavable proinsulin (hppI4), or green fluorescent protein (GFP) only (BMNIG). Non-transduced keratinocytes served as control. The fraction of transduced cells was measured using flow cytometry when cells reached $90 \%$ to $95 \%$ confluence (5-6 days post-seeding). All values are the mean \pm standard deviation of triplicate samples in a representative experiment $(n=3)$.

adipocytes were cultured to confluence, and the medium was replaced with induction medium-1 (IM1) for 3 to 6 days, followed by IM 2 for 3 days and maintenance medium for another 4 to 6 days before adipocytes were used in glucose uptake assays. Maintenance medium was composed of DMEM plus $1 \%$ P/S plus $10 \%$ fetal bovine serum (FBS; Gibco BRL); IM2 was the same as maintenance medium supplemented with $1 \mu \mathrm{g} / \mathrm{mL}$ insulin; IM1 was the same as IM2 supplemented with $1 \mu \mathrm{M}$ dexamethasone and $0.5 \mathrm{mM}$ 1-isobutyl-3-methylxanthine (Aldrich, St Louis, MO).

Human keratinocytes were isolated from neonatal foreskins following the protocol established by Green et $a l .{ }^{25}$ and expanded on feeder layers of 3T3-J2 mouse fibroblasts (ATCC, Manassas, VA) as described previously. ${ }^{26}$ Keratinocytes used in experiments were maintained in keratinocyte serum-free medium (keratinocyte SFM; Gibco BRL) within 1 to 4 passages. Two human epidermal cell lines (HaCaT cells, kindly provided by Dr. Satrajit Sinha; State University of New York at Buffalo, Buffalo, NY, and A431 epidermoid carcinoma cells, ATCC) were cultured in DMEM supplemented with $1 \% \mathrm{P} / \mathrm{S}$ and $10 \% \mathrm{FBS}$ at $37^{\circ} \mathrm{C}$ with $10 \% \mathrm{CO}_{2}$.

\section{Transduction protocol}

Non-tissue culture-treated 24-well plates were incubated overnight at $4{ }^{\circ} \mathrm{C}$ with $400 \mu \mathrm{L}$ of recombinant fibronectin (rFN) fragment CH296 (Takara Mirus Bio Corporation, Madison, WI) in deionized water $(10 \mu \mathrm{g} / \mathrm{mL})$. Retrovirus $(250-400 \mu \mathrm{L} /$ well $)$ was added in $\mathrm{rFN}$-coated wells and incubated at $37^{\circ} \mathrm{C}$ in the presence of $10 \% \mathrm{CO}_{2}$ for 6 to $7 \mathrm{~h}$ (transduction with $\mathrm{rFN}$-immobilized retrovirus). At the end of virus incubation, human epidermal keratinocytes were added at $12,500 \mathrm{cells} / \mathrm{cm}^{2}$ in $500 \mu \mathrm{L}$ of keratinocyte SFM. The next day $(\sim 24 \mathrm{~h}$ later $)$, a fresh stock of retrovirus without polybrene was added to the cells (transduction on $\mathrm{rFN}$ ). After $2 \mathrm{~h}$ of incubation, retrovirus was removed from all wells and replaced with fresh keratinocyte SFM. The medium was replenished every 2 to 3 days until the cells reached $80 \%$ to $90 \%$ confluence, at which time they were processed for flow cytometry.

\section{Flow cytometry}

Keratinocytes were washed once with $0.48 \mathrm{mM}$ ethylenediaminetetraacetic acid (EDTA, Sigma, St. Louis, MO) in phosphate buffered saline (PBS) and detached from the surface uisng trypsin-EDTA (Gibco BRL). The trypsin was inactivated with culture medium containing $10 \%$ FBS, cells were centrifuged ( $5 \mathrm{~min} ; 800 \mathrm{~g}$ ) and resuspended in PBS with $1.0 \mu \mathrm{g} / \mathrm{mL}$ of propidium iodide (PI; Molecular Probes, Grand Island, NY) for $15 \mathrm{~min}$ at $4^{\circ} \mathrm{C}$. Only viable cells (PI-) were used to determine the fraction of transduced (GFP+) cells.

\section{Measurement of proinsulin and C-peptide}

When modified cells reached confluence, they were replenished with fresh keratinocyte SFM. Subsequently, conditioned medium was harvested daily and stored at $-75^{\circ} \mathrm{C}$ until use. The amount of proinsulin was quantified using an enzyme-linked immunosorbent assay (ELISA) kit for human proinsulin (Human Total Proinsulin ELISA Kit; Linco Research, Inc., St. Charles, MO), and the amount of C-peptide was measured using an ELISA kit for human C-peptide (Human C-Peptide ELISA Kit; Linco Research, Inc.), according to the manufacturer's instructions.

\section{Glucose uptake assay}

Mouse adipocytes were serum starved for 1.5 to $2.5 \mathrm{~h}$, followed by stimulation with conditioned medium from 
keratinocytes for $15 \mathrm{~min}$ at $5 \% \mathrm{CO}_{2}$ and $37^{\circ} \mathrm{C}$. Next, cells were incubated with ${ }^{14} \mathrm{C}$-deoxyglucose $(0.05 \mu \mathrm{Ci}$, final concentration $60 \mathrm{mM}$ ) in Krebs-Ringer-phosphate 4-(2hydroxyethyl)-1-piperazineethanesulfonic acid (HEPES) buffer (10 mM HEPES, pH 7.4; 131.2 mM sodium chloride; $4.7 \mathrm{mM}$ potassium chloride; $1.2 \mathrm{mM}$ magnesium sulfate; $2.5 \mathrm{mM}$ calcium chloride $\left(\mathrm{CaCl}_{2}\right) ; 2.5 \mathrm{mM}$ sodium dihydrogen phosphate) for $5 \mathrm{~min}$ at $5 \% \mathrm{CO}_{2}$ and $37^{\circ} \mathrm{C}$. At the end of incubation, cells were placed immediately on ice to inhibit uptake. After 4 washes with ice-cold PBS, cells were lyzed with lysis buffer $(200 \mu \mathrm{L}$ of $2 \%$ deoxycholate and $10 \mu \mathrm{L}$ of $10 \mathrm{~N}$ sodium hydroxide) for $1 \mathrm{~h}$ at $37^{\circ} \mathrm{C}$, and radioactivity was measured using a scintillation counter.

\section{Generation of hppI4 +/furin + HaCaT cells}

$\mathrm{HaCaT}$ cells were transduced using a retrovirus encoding for hppI4 as described above. Once the cells became confluent, they were sorted for GFP expression using fluorescence activated cell sorting. After sorting, the insulin-expressing hppI $4+$ cells were seeded at a density of 25,000 cells $/ \mathrm{cm}^{2}$ in 6-well tissue culture-treated plates. Two days later, hppI4 + cells were transiently transfected with pcDNA3.1-furin (generously provided by Dr. James Binley, The Scripps Research Institute, La Jolla, CA) using Lipofectamine reagent (Gibco BRL). Briefly, pcDNA3.1-furin ( $2 \mu \mathrm{g}$ per $2.5 \times 10^{5}$ cells) and lipofectamine were mixed in a $1 \mu \mathrm{g}: 4 \mu \mathrm{L}$ ratio in $500 \mu \mathrm{L}$ of DMEM without serum or antibiotics. The mixture was incubated at room temperature for 15 to $45 \mathrm{~min}$. At the end of incubation, the mixture was added to hppI 4 + cells in DMEM without serum or antibiotics for $6 \mathrm{~h}$. The medium was replaced, and 2 days later, transfected cells were passed at clonal density and grown in selection medium (DMEM with $1 \% \mathrm{P} / \mathrm{S}, 10 \% \mathrm{FBS}$, and $0.8 \mathrm{mg} / \mathrm{mL} \mathrm{Ge}-$ neticin; G418; Gibco BRL) for 2 weeks. Colonies of selected hppI 4 / furin + cells were pooled and maintained in se- lection medium containing a lower concentration of G418 $(0.4 \mathrm{mg} / \mathrm{mL})$.

\section{Polymerase chain reaction}

Polymerase chain reaction (PCR) was performed using the iCycler (BioRad Laboratories, Hercules, CA). The reaction was carried out in a volume of $50 \mu \mathrm{L}$ containing 20 or $200 \mathrm{ng}$ of plasmid deoxyribonucleic acid (DNA), $2 \mu \mathrm{M}$ of each primer (Sigma Genosys, Woodlands, TX), $200 \mu \mathrm{M}$ of each deoxyribonucleotide triphosphate (dNTP), and 2.5 units of polymerase (PfuUltra HF DNA polymerase; Stratagene, La Jolla, CA). The annealing temperature and magnesium chloride $\left(\mathrm{MgCl}_{2}\right)$ concentrations for each reaction were optimized to maximize product formation and minimize primer-dimer formation (Table 1). The specificity of the PCR products was confirmed using electrophoresis on $0.7 \%$ agarose gels.

\section{Site-directed mutagenesis of proinsulin B chain}

A 3-step PCR was used to create the histidine $(\mathrm{H})$ to aspartic acid (D) mutation at the tenth amino acid on the B-chain of proinsulin (hppI4HD). First, to create the point mutation on the sense DNA, the plasmid pBMN(hppI4)IG was subjected to PCR using primers 2 and 3 as forward and reverse primers, respectively (Table 1 ). Next, to create mutation on the antisense DNA, a second PCR was performed using primers 1 and 4 (Table 1). Finally, the 2 PCR products were subjected to 8 cycles of primerless PCR, followed by 25 cycles of PCR with primers 1 and 2 . Briefly a $50-\mu \mathrm{L}$ reaction mixture containing $10 \mu \mathrm{L}$ each of the PCR products from the first 2 PCRs, $200 \mu \mathrm{M}$ of each dNTP, high-fidelity polymerase, and the corresponding buffer was prepared. After 8 cycles of PCR at an annealing temperature of $65^{\circ} \mathrm{C}$ and $1.5 \mathrm{mM} \mathrm{MgCl}_{2}$, primers were added to a final concentration

Table 1. Polymerase Chain Reaction Conditions and Primers

\begin{tabular}{|c|c|c|c|}
\hline Primer & Primer Sequence & $\begin{array}{c}\text { Magnesium Chloride } \\
\text { Concentration }(m M)\end{array}$ & $\begin{array}{c}\text { Annealing } \\
\text { Temperature }\left({ }^{\circ} \mathrm{C}\right)\end{array}$ \\
\hline 1 & 5'-CCCCACCGCCCTCAAAGTAGACG-3' & 2.5 & 55 \\
\hline 2 & 5'-AAAGACGGCAATATGGTGGAAAAT- $3^{\prime}$ & 1.5 & 50 \\
\hline 3 & 5'-CACCTGTGCGGCTCAGACCTGGTGGAAGCTCTC-3' & 1.5 & 50 \\
\hline 4 & 5'-GAGAGCTTCCACCAGGTCTGAGCCGCACAGGTG-3' & 2.5 & 55 \\
\hline 5 & 5'-TTCTACACACCCAAGACCCGTCGCCGGAAGCGAGAGGAC-3' & 2.5 & 71 \\
\hline 6 & 5'-GTCCTCTCGCTTCCGGCGACGGGTCTTGGGTGTGTAGAA-3' & 2.5 & 71 \\
\hline 7 & 5'-TTGGCCCTGGAGGGGTCTCGTCGGCGGAAGCGTGGCATT-3' & 2.5 & 71 \\
\hline 8 & 5'-AATGCCACGCTTCCGCCGACGAGACCCCTCCAGGCCAA-3' & 2.5 & 71 \\
\hline 9 & 5'-TTCTACACACCCAAGACCCGACGACGCCGGAAGCGAGAGGAC-3' & 2.5 & 66 \\
\hline 10 & 5'-GTCCTCTCGCTTCCGGCGTCGTCGGGTCTTGGGTGTGTAGAA-3' & 2.5 & 66 \\
\hline 11 & 5'-TTGGCCCTGGAGGGGTCTCGACGACGGCGGAAGCGTGGCATTGTG-3' & 2.5 & 71 \\
\hline 12 & 5'-CACAATGCCACGCTTCCGCCGTCGTCGAGACCCCTCCAGGGCCAA-3' & 2.5 & 71 \\
\hline 13 & 5'-AAGGGGACGCGTCCATGGTGAGCAAGGGCGAG-3' & 2.5 & $68-75$ \\
\hline 14 & 5'-AAGGGGGATATCGTCGACCACTGTGCTGGCGC-3' & 2.5 & $68-75$ \\
\hline
\end{tabular}


of $2 \mu \mathrm{M}$ each, and PCR was allowed to run for 25 additional cycles. Subsequently, the PCR product was subcloned into pCR2.1TOPO vector (Invitrogen, Grand Island, NY) according to the manufacturers' instructions, and the resulting plasmid was named TOPO-hppI4-HD. To generate retroviral vector encoding for hppI4-HD, the insert hppI4-HD from TOPO-hppI4-HD was digested using BamHI and ligated into the MCS of pQCXIP $(\mathrm{P}=$ puromycin resistant gene; Clontech, Palo Alto, CA) and pQCXIG ( $\mathrm{G}=\mathrm{GFP}$; described below). The resulting plasmids were called pQC(hppI4HD)IP and pQC(hppI4-HD)IG, respectively (Fig. 1A).

The plasmid pQCXIG was derived from pQCXIX (Clontech). Briefly, the $g f p$ gene sequence from pBMNIG was amplified by PCR using primers that added MluI and EcoRV sites to the $5^{\prime}$ and $3^{\prime}$ ends of the gene, respectively (primers 13 and 14; Table 1). The reaction product was digested using MluI and EcoRV and subsequently ligated into the second MCS of pQCXIX. Retroviral plasmids pQC (hppI1/4)IP and pQC(hppI1/4)IG were generated by digesting hppI1/4 from pBMN(hppI1/4)IG with BamHI and ligating into the MCS of PQCXIP and PQCXIG, respectively (Fig. 1A). All plasmids were sequenced before use.

\section{Site directed mutagenesis at furin consensus sequences}

Introduction of an extra 1 or 2 arginines (R) at the furin cleavages sites was achieved using the QuikChangeII SiteDirected Mutagenesis Kit (Stratagene), according to the manufacturer's instructions (Table 2). First, to insert an additional $\mathrm{R}$ in the furin consensus sequence at the B-C junction, $\mathrm{PCR}$ was performed using TOPO-hppI4-HD as template and primers 5 and 6 (Table 1). The resulting vector, TOPO-hppI4HD-BR1, was used as a PCR template, along with primers 7 and 8 to add one $\mathrm{R}$ to the furin consensus sequence at the A-C junction. The resulting product, TOPO-hppI4-HD-BR1AR1, was used as a PCR template along with primers 9 and 10 to introduce an additional $\mathrm{R}$ in the furin consensus sequence at the B-C junction, yielding construct TOPO-hppI4-HDBR2AR1. Finally, insulin containing 2 extra R's in each furin cleavage site was created using TOPO-hppI4-HDBR2AR1 as a PCR template and primers 11 and 12. After

Table 2. Proinsulin-Encoding Constructs with Different Mutations in the B Chain And at the A-C and B-C Junctions

\begin{tabular}{lccc}
\hline & & \multicolumn{2}{c}{$\begin{array}{c}\text { Furin Consensus } \\
\text { Sequence }\end{array}$} \\
\cline { 3 - 4 } Name & $\begin{array}{c}\text { H to D Mutation } \\
\text { at Position B10 }\end{array}$ & $\begin{array}{c}\text { A-C } \\
\text { junction }\end{array}$ & $\begin{array}{c}\text { B-C } \\
\text { junction }\end{array}$ \\
\hline hppI4 & No & RRKR & RRKR \\
hppI4-HD & Yes & RRKR & RRKR \\
hppI4-HD-BR1AR1 & Yes & RRRKR & RRRKR \\
hppI4-HD-BR2AR2 & Yes & RRRRKR & RRRRKR \\
\hline
\end{tabular}

generating all the mutants in the TOPO vector, the mutated proinsulin sequences were subsequently digested using BamHI and ligated into the MCS of pQCXIP or pQCXIG. All plasmids were sequenced before use.

\section{Preparation of skin equivalents}

Skin equivalents were prepared as previously described. ${ }^{27-29}$ Briefly, square pieces of acellular dermis $\left(1 \mathrm{~cm}^{2}\right)$ were placed, basement membrane side up, into 6well tissue-culture dishes. A freshly prepared suspension of keratinocytes from 3T3-J2 feeder layers $\left(5 \times 10^{6}\right.$ cells $\left./ \mathrm{mL}\right)$ in keratinocyte seeding medium (described below) was added onto the papillary side of the dermis $(\sim 100 \mu \mathrm{L}$, or enough to cover the surface) or on collagen-coated polycarbonate membranes (Transwell, Corning Costar, Cambridge, MA). Approximately $1.5 \mathrm{~h}$ after cell seeding, the skin equivalents were submerged in keratinocyte seeding medium for $24 \mathrm{~h}$. Keratinocyte seeding medium was a 3:1 mixture of DMEM and Ham's F-12 medium (Gibco BRL) supplemented with $1 \% \mathrm{FBS}, 1 \% \mathrm{P} / \mathrm{S}, 10^{-10} \mathrm{M}$ cholera toxin (Vibrio cholerae, type Inaba 569 B; Calbiochem, La Jolla, CA), $0.4 \mu \mathrm{g} / \mathrm{mL}$ hydrocortisone (Calbiochem), and $5 \mu \mathrm{g} / \mathrm{mL}$ recombinant insulin (Sigma). After $24 \mathrm{~h}$, keratinocyte seeding medium was removed, and the skin equivalents were submerged for an additional $48 \mathrm{~h}$ in a keratinocyte priming medium. Keratinocyte priming medium was composed of keratinocyte seeding medium supplemented with $24 \mu \mathrm{M}$ bovine serum albumin, $1.0 \mathrm{mM}$ L-serine, $10 \mu \mathrm{M} \mathrm{L}$-carnitine, and a cocktail of fatty acids ( $25 \mu \mathrm{M}$ oleic acid, $15 \mu \mathrm{M}$ linoleic acid, $7 \mu \mathrm{M}$ arachidonic acid, and $25 \mu \mathrm{M}$ palmitic acid (all Sigma)) ${ }^{30}$ After $48 \mathrm{~h}$ in priming medium, skin equivalents were placed on stainless steel screens, raised to the air-liquid interface, and cultured with an air-liquid interface medium composed of serum-free keratinocyte priming medium supplemented with $1 \mathrm{ng} / \mathrm{mL}$ epidermal growth factor (Collaborative Biomedical Products, Bedford, MA). Skin equivalents were cultured at the air-liquid interface for 7 days, with airliquid interface medium replaced every 3 days, or daily for Cpeptide/proinsulin measurements.

\section{Histology and immunohistochemistry}

For histology, skin equivalents were embedded in paraffin and stained with hematoxylin and eosin, as previously described. ${ }^{27,29}$ For fluorescence imaging, skin equivalents were fixed in $4 \%$ paraformaldehyde in PBS for $4 \mathrm{~h}$ at $4{ }^{\circ} \mathrm{C}$, followed by treatment with $0.1 \mathrm{M}$ ice-cold glycine for $1 \mathrm{~h}$ and overnight incubation in $0.6 \mathrm{M}$ sucrose solution at $4^{\circ} \mathrm{C}$. Tissues were embedded in O.C.T. (Sakura Finetek, Torrance, $\mathrm{CA}$ ), frozen on dry ice, and kept at $-75^{\circ} \mathrm{C}$ until use. To visualize GFP, the sections were washed twice with PBS and mounted with an aqueous mounting medium (Gel/ Mount; Biomeda, Foster City, CA). Fluorescent images of the sections were obtained using an inverted fluorescence microscope (Nikon Diaphot, Garden City, NY). 


\section{Statistical analysis}

Statistical analysis of the data was performed using the Tukey's honestly significant difference test $(\alpha=0.05)$.

\section{RESULTS}

\section{Efficient transduction of primary human keratinocytes using proinsulin-encoding retrovirus}

We transduced primary human keratinocytes with retrovirus encoding for the proinsulin gene that was modified to contain furin cleavage sites in place of the regular convertase sites. ${ }^{24}$ Many cell types, including keratinocytes, which do not express the proprotein convertases PC $1 / 3$ and PC2 that are required for proinsulin processing, ubiquitously express the protease furin. ${ }^{31}$ Proinsulin with (hppI4) or without (hppI1) furin cleavage sites was cloned into the retroviral vector $\mathrm{pBMNIG}$ under the viral LTR, followed by the IRES and GFP (Fig. 1A). IRES permits expression of hppI1/ 4 and GFP from the same promoter, and because IRES is partially inactivated, GFP is expressed to a lesser extent than proinsulin. As a result, all cells that express GFP should express even higher amounts of hppI1/4.

Keratinocytes were transduced on $\mathrm{rFN}$ using a protocol that yielded high efficiencies of retroviral gene transfer to primary human keratinocyte stem cells. ${ }^{29}$ Specifically, keratinocytes were plated on $\mathrm{rFN}$-coated plates preloaded with retrovirus and the next day exposed to the virus for another $2 \mathrm{~h}$. Polybrene was not used in either step, because previous studies have showed that polybrene decreased gene transfer by inhibiting binding of retrovirus to the heparinbinding domain of $\mathrm{rFN} .^{32,33}$ This protocol yielded approximately $60 \%$ transduced GFP + cells, as determined using flow cytometry (Fig. 1B).

\section{Primary human keratinocytes express high levels of proinsulin and insulin}

The amount of proinsulin secreted from the hppI1- and hppI4-transduced cells was 10 and $0.2 \mathrm{pmol}$ proinsulin $/ 10^{6}$ cells per day, respectively, as determined using ELISA. As expected, no proinsulin was observed in non-transduced cells or cells transduced with the control BMNIG retrovirus (Fig. 2A).

Because exogenous insulin in the culture medium is required to maintain keratinocyte cell proliferation, ${ }^{34,35}$ we quantified the amount of insulin secreted from transduced cells by measuring the amount of C-peptide using ELISA. The antibody that was used in this assay recognized free $\mathrm{C}$ peptide as well as $\mathrm{C}$-peptide in intact proinsulin. The amount of C-peptide from hppI1 cells was 8 to $10 \mathrm{pmol} / 10^{6}$ cells per day, confirming the proinsulin data (Fig. 2B). On the other hand, hppI 4 cells secreted $1.3 \mathrm{pmol} / 10^{6}$ cells per day of C-peptide but only $0.2 \mathrm{pmol} / 10^{6}$ cells per day of proinsulin (Fig. 2A), suggesting that proinsulin was processed into mature insulin successfully.

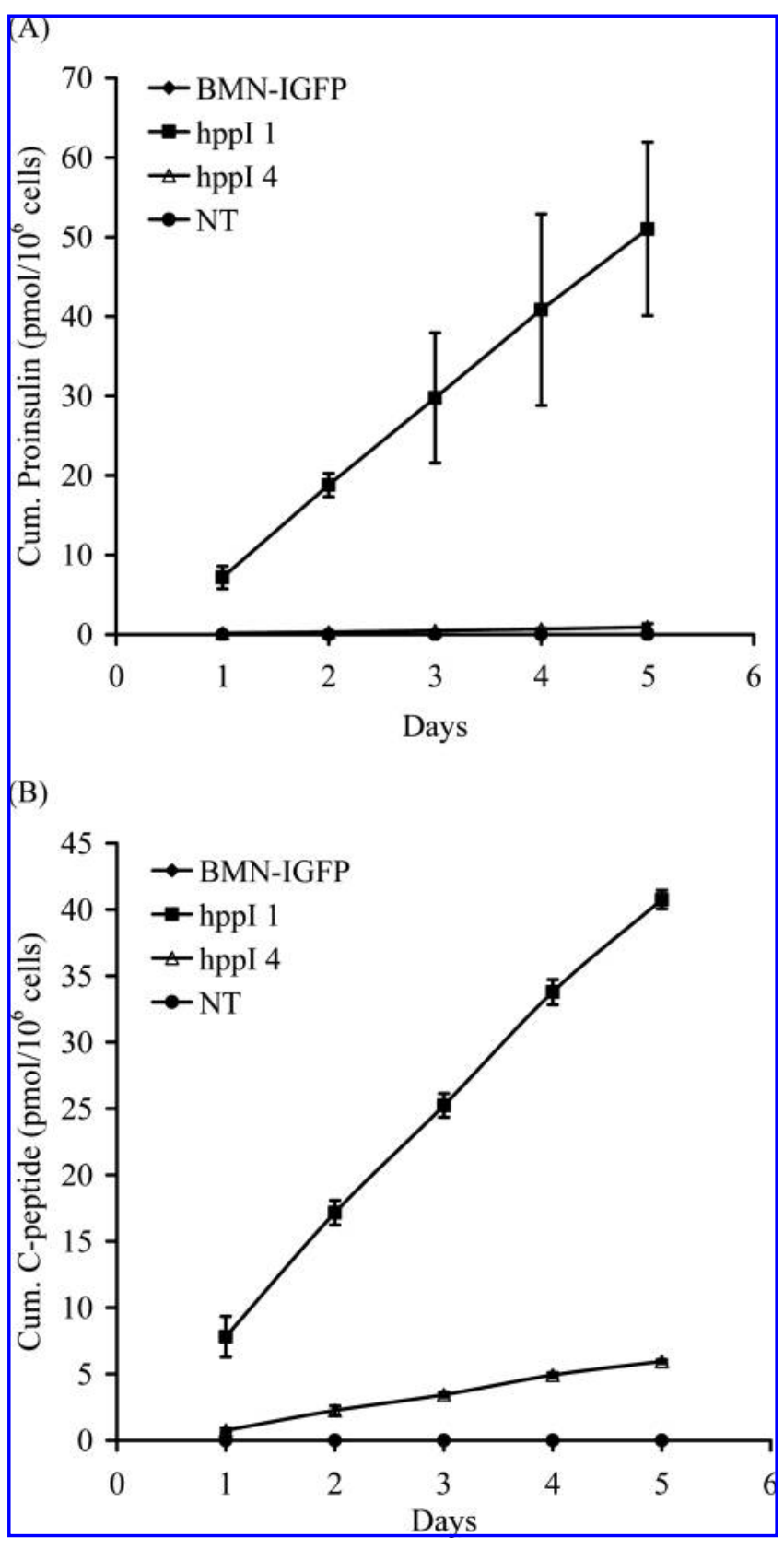

FIG. 2. Proinsulin and insulin production from modified keratinocytes. Human keratinocytes were non-transduced (NT) or transduced with green fluorescent protein (GFP), hppI1, or hppI4 encoding retrovirus. Conditioned medium was harvested daily after the cells reached confluence. The amount of (A) proinsulin or (B) C-peptide was plotted as a function of time. Values were normalized to the number of transduced cells and reported as the mean \pm standard deviation of triplicate samples in a representative experiment $(n=3)$.

\section{Bioengineered skin equivalents from transduced keratinocytes produce insulin}

Although hppI4 keratinocytes secreted insulin in conventional cell culture, it was not certain whether these cells retained the ability to stratify into insulin-producing 3D skin 
substitutes. To address this point, we engineered skin equivalents by seeding hppI 4 keratinocytes on decellularized dermis and raising them to the air-liquid interface. We found that hppI 4 cells developed into a fully stratified epithelium with basal, suprabasal, granular, and cornified layers, similar to control, non-transduced cells (Fig 3A, B; hematoxylin and eosin). Fluorescence microscopy of cryosections revealed GFP expression throughout the epidermis, with the highest levels detected in the suprabasal layers (Fig. 3C), in accordance with our previous observations. ${ }^{29}$ Similar results were observed with hppI1 tissues (data not shown). HppI1 tissues secreted C-peptide at a rate of $10 \mathrm{pmol} / \mathrm{cm}^{2}$ tissue per day for the first 4 days, but the rate declined at later times, approaching a plateau by day 7 . On the other hand, hppI 4 tissues secreted C-peptide at a constant rate of $2.5 \mathrm{pmol} / \mathrm{cm}^{2}$ tissue per day over 7 days in culture at the air-liquid interface (Fig. 3D).

\section{Upregulation of furin enhances insulin production}

In 2D and 3D cell culture systems, C-peptide production from hppI4 cells was consistently lower than that from hppI1 cells, despite similar transduction efficiencies. Because production of insulin from hppI 4 cells requires the action of furin, we hypothesized that expression of furin may limit proinsulin processing. To address this hypothesis, we transduced $\mathrm{HaCaT}$ cells, an epidermal cell line, with hppI4 encoding retrovirus and sorted GFP + cells using flow cytometry. After expansion, hppI4 cells were transfected with a plasmid encoding for the furin gene and selected in G418-containing medium for 2 weeks. The amount of Cpeptide that hppI 4 /furin + cells secreted was three times greater than that of control hppI4 + cells (Fig. 4), suggesting that the proteolytic activity of furin may limit processing of proinsulin in epidermal keratinocytes.
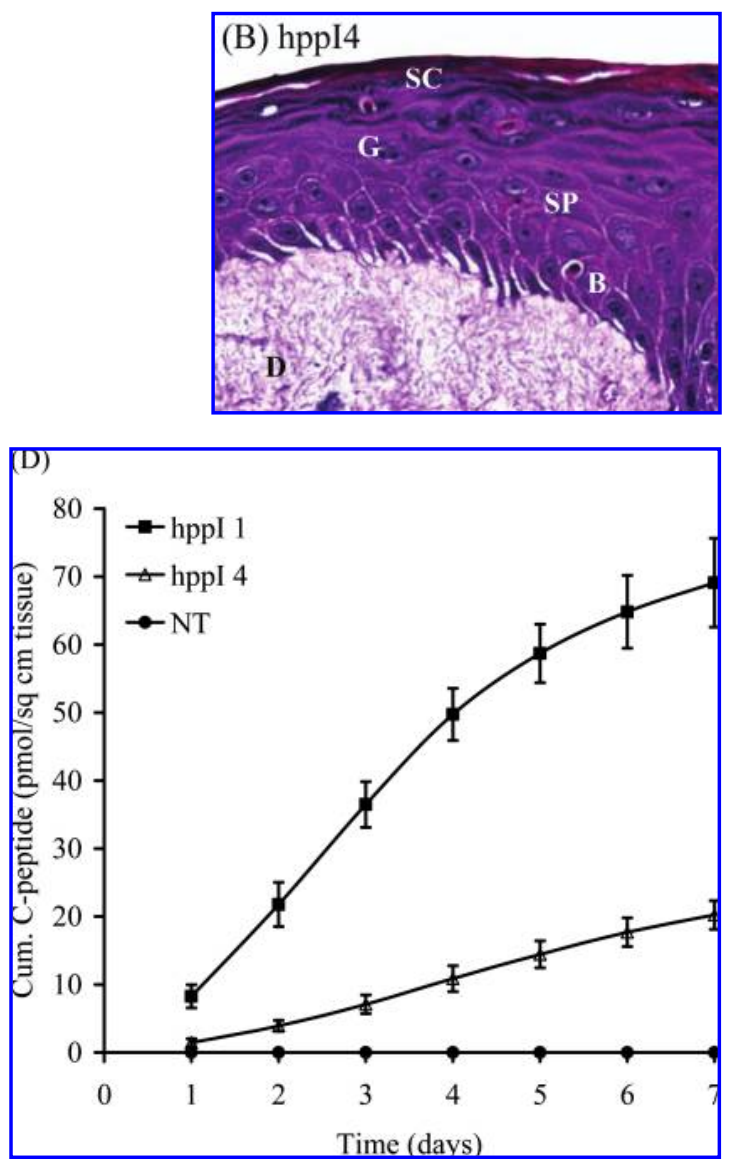

FIG. 3. Proinsulin and insulin production from modified tissue-engineered skin equivalents. Human keratinocytes were non-transduced (NT) or transduced with hppI1 or hppI4 encoding retrovirus. Skin equivalents were generated by seeding keratinocytes onto the papillary side of decellularized dermis and raising them to the air-liquid interface for 7 days to allow complete stratification. Paraffin sections of skin equivalents from (A) NT or (B) hppI4 keratinocytes were stained with hematoxylin and eosin (40x). (C) Frozen sections of hppI4 tissues after 7 days at the air-liquid interface were used to evaluate gene expression (GFP, green; 40x). The dotted line denotes the basement membrane that separates the epidermis from the dermis. (D) Conditioned medium was harvested from skin equivalents daily after they were raised to the air-liquid interface. C-peptide in conditioned medium was detected using enzyme-linked immunosorbent assay and reported as cumulative amount of C-peptide levels normalized to the area of the tissue $\left(\right.$ per $\left.\mathrm{cm}^{2}\right)$. All values are the mean \pm standard deviation of triplicate samples in a representative experiment $(n=3)$. B, basal; SP, suprabasal; G, granular; SC, cornified (stratum corneum) cell layers; and D: dermis. Color images available online at www.liebertpub.com/ten. 


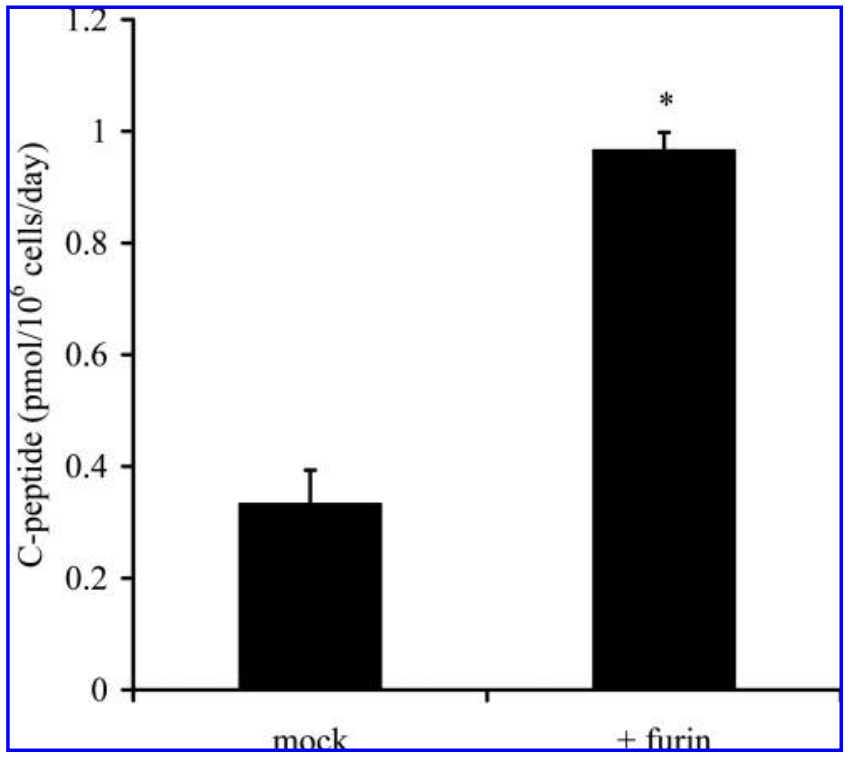

FIG. 4. Overexpression of furin increases proinsulin processing. $\mathrm{HaCaT}$ cells were transduced with retrovirus encoding for hppI4. Once the cells reached confluence, hppI 4 + cells were sorted using fluorescence activated cell sorting. The hppI $4+$ cells were transfected with pcDNA3.1-furin using lipofectamine and selected with Geneticin (G418) for 2 weeks. The amount of C-peptide from hppI 4 + or hppI 4 +/furin + was measured using enzyme-linked immunosorbent assay. All values are the mean \pm standard deviation of triplicate samples in a representative experiment $(n=3)$.

\section{An amino acid substitution increases insulin production by epidermal keratinocytes significantly}

Previous studies have reported that a point mutation at the tenth amino acid of the proinsulin B-chain increased binding to insulin receptor and the activity of insulin significantly. ${ }^{36,37}$ Others showed that furin is a relatively slow enzyme and that altering the furin consensus sequence increased the cleavage efficiency of the human immunodeficiency virus (HIV) envelope precursor gp $160 .^{38}$ Based on these results, we attempted to increase the amount of insulin from hppI4 keratinocytes by taking a 2-prong approach. First, we mutated the tenth amino acid in the proinsulin Bchain from histidine to aspartic acid (HB10D) and used the resulting vector as a template for site-directed mutagenesis to introduce additional arginines in the furin recognition sequences at the A-C and B-C junctions (Table 2). The resulting proinsulin genes were then cloned into a selfinactivating retroviral vector, pQCXIP (Fig. 1A). HaCaT cells and A431 squamous carcinoma cells were transduced with recombinant retrovirus encoding for the altered proinsulin constructs and selected with puromycin.

The HB10D substitution resulted in 6- or 10-fold increase in C-peptide production from $\mathrm{HaCaT}$ or A431 cells, respectively (Fig. 5). On the other hand, changes in the furin recognition sequence did not increase insulin production. In contrast, an extra arginine at the A-C and B-C furin cleavage sites (BR1AR1) resulted in a moderate reduction $(\sim 25 \%)$ in C-peptide secretion from A431 cells. The decrease was more pronounced $(\sim 50 \%)$ when 2 additional arginines were inserted in the furin consensus sequence (BR2AR2). $\mathrm{HaCaT}$ cells yielded a significantly lower level of C-peptide than A431 cells and remained unaffected by changes in the furin cleavage sites.

To examine whether altered proinsulin constructs had similar effects on primary cells, we cloned the mutated proinsulin genes into the pQCXIG retroviral plasmid (Fig. 1A) that encodes for GFP instead of puromycin, thus allowing quantitation of transduced cells using flow cytometry. Keratinocytes transduced with the pQC(hppI4)IG retroviral vector secreted higher levels of C-peptide $\left(4.6 \mathrm{pmol} / 10^{6}\right.$ cells per day) than those transduced with the pBMN(hppI4)IG vector $\left(1.3 \mathrm{pmol} / 10^{6}\right.$ cells per day), possibly reflecting differences in strength of the 2 promoters (viral LTR vs. cytomegalovirus). Most important, the $\mathrm{H}$ to $\mathrm{D}$ substitution increased C-peptide production by about 10 -fold, reaching $45.5 \mathrm{pmol} / 10^{6}$ cells per day (or $8 \mathrm{mU} / 10^{6}$ cells per day) (Fig 6A). Addition of 1 or 2 arginines at the furin cleavage sites did not enhance C-peptide production any further. As expected, the proinsulin level from modified cells was low, suggesting that the mutations did not adversely affect proinsulin processing in keratinocytes.

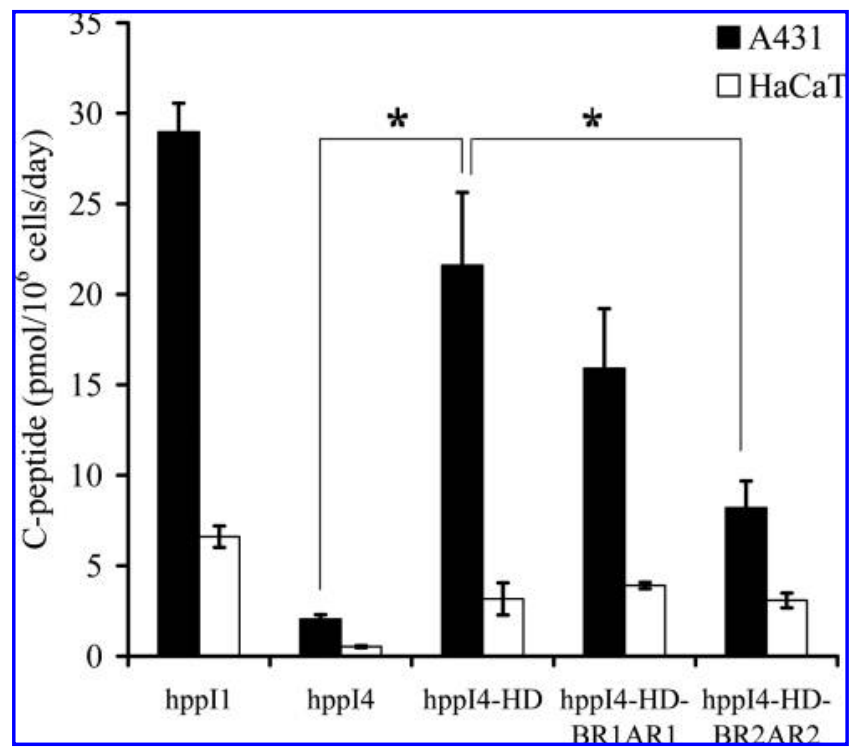

FIG. 5. A single amino acid mutation in the B-chain of proinsulin (HB10D) enhanced C-peptide secretion significantly. HaCaT and A431 epidermal cell lines were each transduced with retroviruses encoding for hppI4, hppI4-HD, hppI4-HD-BR1AR1, or hppI4HD-BR2AR2. After 2 weeks of antibiotic selection in puromycin, C-peptide secretion from modified cells was measured using enzyme-linked immunosorbent assay. All values are the mean \pm standard deviation of triplicate samples in a representative experiment $(n=3)$. The asterisks $(*)$ denote $p<0.05$ between the indicated samples. 

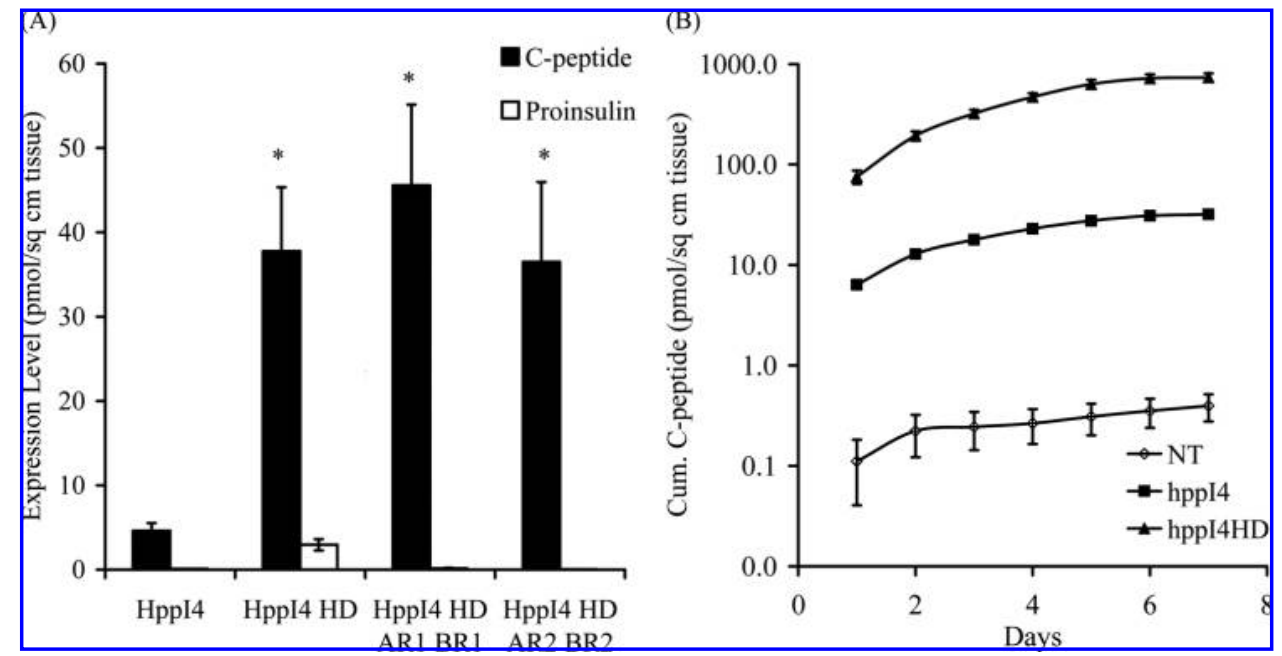

FIG. 6. High levels of insulin production from gene-modified human primary keratinocytes. Human keratinocytes were transduced with retroviruses encoding for hppI4, hppI4-HD, hppI4-HD-BR1AR1, or hppI4-HD-BR2AR2. (A) The daily secretion of proinsulin and C-peptide from modified cells was measured using enzyme-linked immunosorbent assay (ELISA) and normalized to the number of transduced cells. The asterisk $(*)$ denotes $p<0.05$ between the indicated samples and control (hppI4). (B) In parallel, transduced cells were sorted for green fluorescent protein-positive cells and expanded on 3T3/J2 fibroblasts. The cells were then seeded on collagencoated polycarbonate membranes and raised to the air-liquid interface to allow complete stratification. Thereafter, conditioned medium was harvested daily, and the level of C- peptide was measured using ELISA. (A, B) All values are the mean \pm standard deviation of triplicate samples in a representative experiment $(n=2)$.

To evaluate insulin secretion from stratified tissues, keratinocytes were modified with hppI4 or hppI4-HD retrovirus and used to prepare bioengineered skin. We found that hppI4 and hppI4-HD tissues secreted C-peptide at a rate of 5 and $140 \mathrm{pmol} / \mathrm{cm}^{2}$ tissue per day, respectively. These data show that the $\mathrm{H}$ to $\mathrm{D}$ mutation increased secretion from 3D tissues to a larger extent than cells in culture (28- vs. 10fold), suggesting that stratification may have increased the ability of keratinocytes to express and process proinsulin significantly (Fig. 6B).

\section{Insulin secreted by keratinocytes is biologically active}

To determine whether insulin produced by keratinocytes was active, we measured glucose uptake by mouse adipocytes (3T3-L1) in response to conditioned medium from genetically modified keratinocytes. In accordance with the ELISA data, treatment of 3T3-L1 cells with conditioned medium from hppI4 and hppI4-HD cells enhanced glucose uptake 4- and 33-fold, respectively, over conditioned medium from unmodified cells (Fig. 7). These data indicate that wild-type and mutated insulin produced from epidermal keratinocytes remained biologically active. The specific activity (glucose uptake per ng of C-peptide) of conditioned medium from hppI4 cells was similar to that of hppI4-HD cells, suggesting that increased glucose uptake was due to increased production of insulin (hppI4-HD) rather than superior binding to the insulin receptor.

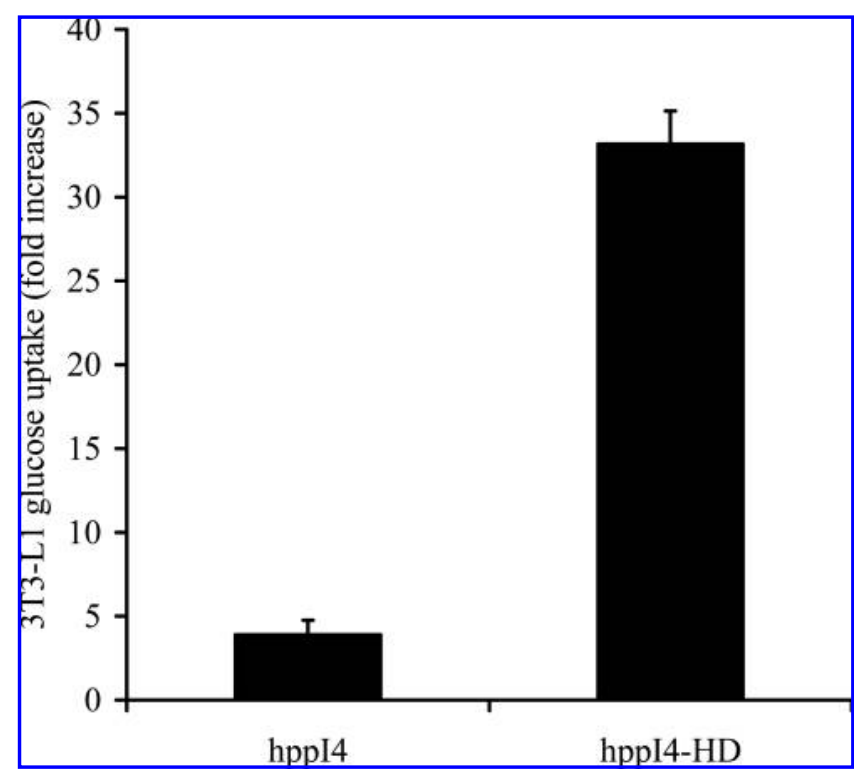

FIG. 7. Insulin produced by keratinocytes is biologically active. Modified keratinocytes were cultured to confluence and switched to Dulbecco's modified Eagle medium $+100 \mathrm{U}$ of penicillin and $100 \mu \mathrm{g} / \mathrm{mL}$ streptomycin and $10 \%$ dialyzed (insulin-free) fetal bovine serum. After $24 \mathrm{~h}$, conditioned medium was harvested and used to stimulate 3 T3-L1 cells. Glucose $\left({ }^{14} \mathrm{C}\right.$-DOG) uptake by adipocytes was quantified and normalized to the uptake level of nonstimulated cells. The values represent the mean \pm standard deviaiton of 2 experiments each containing duplicate samples. 


\section{DISCUSSION}

In the present study, we used recombinant retrovirus to modify human epidermal cells to produce bioactive insulin for treatment of diabetes. First, we modified human primary keratinocytes to produce insulin using a transduction protocol that promoted high transduction efficiency to human epidermal stem cells. ${ }^{29}$ Using this protocol, we transduced approximately $60 \%$ of cells with retroviruses encoding for wild-type proinsulin (hppI1) or furin-cleavable proinsulin (hppI4). Genetically modified keratinocytes maintained their ability to differentiate and stratify in vitro, similar to unmodified cells. Modifications in the furin cleavage sites did not improve proinsulin processing, but furin overexpression or a single amino acid change in the $\mathrm{B}$ chain increased C-peptide secretion significantly. Finally, modified bioengineered skin secreted high amounts of $\mathrm{C}$-peptide and expressed the transgene in the basal and suprabasal layers, in accordance with previous studies. ${ }^{19,29,39}$

HppI1 cells yielded consistently higher levels of C-peptide than hppI4 cells in 2D and 3D cell cultures. Similar results have been shown in other cell types, such as skeletal smooth muscle cells, kidney embryonic epithelial cells, ovary cells, and fibroblasts. ${ }^{40-44}$ Because this difference was not due to dissimilar transduction efficiencies (Fig. 1B), low secretion from hppI4 cells might reflect inefficient processing of proinsulin by furin. Indeed, furin overexpression resulted in 3-fold increase in C-peptide secretion from $\mathrm{HaCaT}$ cells, suggesting that the amount of furin may limit proinsulin processing. However, overexpression of furin did not increase insulin secretion from A431 cells (data not shown), suggesting that other mechanism(s) may also be at work.

In addition to expression level, the enzymatic activity of furin might be low because of lack of co-factors or suboptimal furin recognition sequence in the proinsulin gene. Because the activity of furin was shown to require calcium, ${ }^{45}$ it was possible that treatment with higher calcium concentrations might improve insulin production. However, treatment of keratinocytes with up to $2 \mathrm{mM} \mathrm{CaCl}_{2}$, yielded a modest $50 \%$ increase in $\mathrm{C}$-peptide secretion (data not shown). A recent study showed that introduction of 2 arginines at the furin cleavage sites (RRKR $\downarrow \rightarrow$ RRRRRR $\downarrow$, RRRRKR $\downarrow$, and RRRKKR $\downarrow$ ) enhanced furin activity, resulting in elevated levels of production of the HIV envelope protein gp $120 .^{38}$ In contrast, we found that the same mutations decreased insulin secretion from A431 cells but had no effect on secretion from HaCaT cells or primary keratinocytes, suggesting that the action of furin may depend on the physiological state of the producer cell.

Alternatively, the furin recognition sequence may affect the structure of insulin. Recent studies have showed that Cpeptide plays an important role in folding of proinsulin and its subsequent processing into insulin. ${ }^{46,47}$ In particular, mutations in the highly conserved acidic residues, EAED, at the $\mathrm{N}$ terminus of the $\mathrm{C}$-peptide resulted in protein aggregation during refolding. ${ }^{48}$ To engineer the furin cleavage site at the $\mathrm{B}-\mathrm{C}$ junction, the acidic residue at the $\mathrm{N}$ terminus of $\mathrm{C}$-peptide was converted to a basic residue $(\mathrm{E} \rightarrow \mathrm{R})$. This substitution may have altered the protein folding pattern, resulting in a less stable form of proinsulin, and consequently reduced the level of secreted insulin. ${ }^{47}$

In addition to varying the furin consensus sequence, we attempted to improve insulin production by a single amino acid substitution at the tenth position of the proinsulin Bchain. Previous studies have showed that this single-point mutation enhanced insulin stability and production level 10to 100 -fold compared with wild-type insulin. ${ }^{49}$ The $\mathrm{H}$ to D mutation increased insulin secretion from 2D keratinocyte cultures and 3D skin substitutes 10- and 28-fold, respectively. The higher increase observed in stratified tissues, in accordance with our previous data, ${ }^{29}$ as well as the data of others, ${ }^{19,39}$ showed that differentiated suprabasal keratinocytes expressed higher levels of the transgene than basal cells. Higher transgene expression in suprabasal layers may reflect a higher metabolic state of differentiated keratinocytes or higher expression of furin. No matter what the mechanism may be, this result is important, because the majority of keratinocytes in stratified tissues are situated in the suprabasal layers, suggesting that gene-modified bioengineered skin may be efficient in secreting insulin in vivo.

The daily rate of C-peptide production by hppI4 and hppI4-HD keratinocytes was 4.6 and $45.5 \mathrm{pmol} / 10^{6}$ cells per day, corresponding to 27 and $270 \mathrm{ng}$ of insulin $/ 10^{6}$ cells per day, respectively. These levels are significantly higher than the levels of insulin production by other cell types such as HepG2 (3.6 ng/10 ${ }^{6}$ cells per day), NIH-3T3 (3.1 ng/10 6 cells per day), human fibroblasts $\left(3.9 \mathrm{ng} / 10^{6}\right.$ cells per day), and human myoblasts $\left(13.2 \mathrm{ng} / 10^{6}\right.$ cells per day) transduced with insulin-encoding retrovirus. ${ }^{15}$ Modified keratinocytes retained the ability to stratify, and the resulting bioengineered skin secreted C-peptide at a rate of $140 \mathrm{pmol} / \mathrm{cm}^{2}$ tissue per day. The reported $\mathrm{C}$-peptide concentration in human serum after islet transplantation was approximately $1.0 \mathrm{ng} / \mathrm{mL} .^{50,51}$ The volume of serum is approximately $40 \%$ of the blood volume or $2 \mathrm{~L}$ (assuming $5 \mathrm{~L}$ of blood in a $70-\mathrm{kg}$ adult), yielding a total of 2,000 ng or $625 \mathrm{pmol}$ of C-peptide. Based on the daily rate of $\mathrm{C}$-peptide secretion by skin substitutes ( $140 \mathrm{pmol} / \mathrm{cm}^{2}$ of tissue per day), the stability of C-peptide in serum (half-life $=174 \mathrm{~h}^{52}$ ) and the clearance of C-peptide in blood (half-life $=30-60 \mathrm{~min}^{53}$ ), we calculated that the area of transplanted skin tissue required to produce insulin at a molar amount equal to that of transplanted islets is between $75 \mathrm{~cm}^{2}(8.5 \mathrm{~cm} \times 8.5 \mathrm{~cm})$ and $150 \mathrm{~cm}^{2}(12 \mathrm{~cm} \times 12 \mathrm{~cm})$. The calculated area of skin grafts is only $0.37 \%$ to $0.75 \%$ of the total skin surface area of the average adult $\left(\sim 2 \mathrm{~m}^{2}\right)$, suggesting that bioengineered skin may provide an efficient vehicle for insulin release to substitute or complement insulin injections. Continuous delivery of basal levels of insulin provided by genetically modified cells has been shown to have beneficial effects on glucose levels. ${ }^{7,54,55}$ In this manner, genetically modified skin substitutes may be used as "bioreactors" to provide continuous delivery of basal levels 
of insulin and maintain glucose control under fasting conditions. Depending upon the functionality of the pancreatic islet $\beta$-cells, low doses of exogenous insulin may still be required to maintain normoglycemia after meals. Therefore, the combination of a continuous source of insulin with lower doses of insulin therapy may reduce the number of injections and at the same time provide tight glycemic control, ultimately reducing long-term complications. Finally, molecular switches can be designed and incorporated into our retroviral or lentiviral vectors to provide glucose-controlled secretion of insulin, as demonstrated previously. ${ }^{56-58}$ These systems are currently under development in our laboratory.

\section{ACKNOWLEDGMENTS}

This work was supported by National Institutes of Health Grants R01 DK068699-01 (S.T.A,), R01 DK068673-01 (K.L.K.), and DK068700-02 (S.G.L.).

\section{REFERENCES}

1. Todd, J.A. and Bain, S.C. A practical approach to identification of susceptibility genes for IDDM. Diabetes 41, 1029, 1992.

2. Yoon, J.W. Pathogenesis of IDDM: Environmental Factors. In: Pickup, J., and Williams, G., eds. Textbook of Diabetes. Londen: Blackwell Scientific Publications, 1997, pp. 1-14.

3. Roche, H.M., Phillips, C. and Gibney, M.J. The metabolic syndrome: the crossroads of diet and genetics. Proc Nutr Soc 64, 371, 2005.

4. Chernajovsky, Y., Dreja, H., Daly, G., Annenkov, A., Gould, D., Adams, G., Croxford, J.L., Baker, D., Podhajcer, O.L. and Mageed, R.A. Immuno- and genetic therapy in autoimmune diseases. Genes Immun 1, 295, 2000.

5. Bonner-Weir, S. and Sharma, A. Pancreatic stem cells. J Pathol 197, 519, 2002.

6. Wu, L., Nicholson, W., Wu, C.Y., Xu, M., McGaha, A., Shiota, M. and Powers, A.C. Engineering physiologically regulated insulin secretion in non-beta cells by expressing glucagon-like peptide 1 receptor. Gene Ther 10, 1712, 2003.

7. Bailey, C.J., Davies, E.L. and Docherty, K. Prospects for insulin delivery by ex-vivo somatic cell gene therapy. $\underline{\mathrm{J} \text { Mol }}$ Med 77, 244, 1999.

8. Chen, R., Meseck, M.L. and Woo, S.L. Auto-regulated hepatic insulin gene expression in type 1 diabetic rats. Mol Ther 3, 584, 2001.

9. Chen, R., Meseck, M., McEvoy, R.C. and Woo, S.L. Glucosestimulated and self-limiting insulin production by glucose 6phosphatase promoter driven insulin expression in hepatoma cells. Gene Ther 7, 1802, 2000.

10. Zalzman, M., Gupta, S., Giri, R.K., Berkovich, I., Sappal, B.S., Karnieli, O., Zern, M.A., Fleischer, N. and Efrat, S. Reversal of hyperglycemia in mice by using human expandable insulin-producing cells differentiated from fetal liver progenitor cells. Proc Natl Acad Sci USA 100, 7253, 2003.

11. Ferber, S., Halkin, A., Cohen, H., Ber, I., Einav, Y., Goldberg, I., Barshack, I., Seijffers, R., Kopolovic, J., Kaiser, N. and
Karasik, A. Pancreatic and duodenal homeobox gene 1 induces expression of insulin genes in liver and ameliorates streptozotocin-induced hyperglycemia. Nat Med 6, 568, 2000.

12. Kojima, H., Fujimiya, M., Matsumura, K., Younan, P., Imaeda, H., Maeda, M. and Chan, L. NeuroD-betacellulin gene therapy induces islet neogenesis in the liver and reverses diabetes in mice. Nat Med 9, 596, 2003.

13. Cheung, A.T., Dayanandan, B., Lewis, J.T., Korbutt, G.S., Rajotte, R.V., Bryer-Ash, M., Boylan, M.O., Wolfe, M.M. and Kieffer, T.J. Glucose-dependent insulin release from genetically engineered K cells. Science 290, 1959, 2000.

14. Kolodka, T.M., Finegold, M., Moss, L. and Woo, S.L. Gene therapy for diabetes mellitus in rats by hepatic expression of insulin. Proc Natl Acad Sci USA 92, 3293, 1995.

15. Falqui, L., Martinenghi, S., Severini, G.M., Corbella, P., Taglietti, M.V., Arcelloni, C., Sarugeri, E., Monti, L.D., Paroni, R., Dozio, N., Pozza, G. and Bordignon, C. Reversal of diabetes in mice by implantation of human fibroblasts genetically engineered to release mature human insulin. Hum Gene Ther 10, 1753, 1999.

16. Fenjves, E.S., Schwartz, P.M., Blaese, R.M. and Taichman, L.B. Keratinocyte gene therapy for adenosine deaminase deficiency: a model approach for inherited metabolic disorders. Hum Gene Ther 8, 911, 1997.

17. Fenjves, E.S., Smith, J., Zaradic, S. and Taichman, L.B. Systemic delivery of secreted protein by grafts of epidermal keratinocytes: prospects for keratinocyte gene therapy Hum Gene Ther 5, 1241, 1994.

18. Jensen, T.G., Sullivan, D.M., Morgan, R.A., Taichman, L.B., Nussenblatt, R.B., Blaese, R.M. and Csaky, K.G. Retrovirusmediated gene transfer of ornithine-delta-aminotransferase into keratinocytes from gyrate atrophy patients. Hum Gene Ther 8, 2125, 1997.

19. Sullivan, D.M., Jensen, T.G., Taichman, L.B. and Csaky, K.G. Ornithine-delta-aminotransferase expression and ornithine metabolism in cultured epidermal keratinocytes: toward metabolic sink therapy for gyrate atrophy. Gene Ther $\mathbf{4}, 1036$, 1997.

20. Christensen, R., Kolvraa, S., Blaese, R.M. and Jensen, T.G. Development of a skin- based metabolic sink for phenylalanine by overexpression of phenylalanine hydroxylase and GTP cyclohydrolase in primary human keratinocytes. Gene Ther 7 , 1971, 2000.

21. Fakharzadeh, S.S., Zhang, Y., Sarkar, R. and Kazazian, H.H., Jr. Correction of the coagulation defect in hemophilia A mice through factor VIII expression in skin. Blood 95, 2799, 2000.

22. Larcher, F., Del Rio, M., Serrano, F., Segovia, J.C., Ramirez, A., Meana, A., Page, A., Abad, J.L., Gonzalez, M.A., Bueren, J., Bernad, A. and Jorcano, J.L. A cutaneous gene therapy approach to human leptin deficiencies: correction of the murine ob/ob phenotype using leptin-targeted keratinocyte grafts. Faseb J 15, 1529, 2001.

23. Noel, D., Dazard, J.E., Pelegrin, M., Jacquet, C. and Piechaczyk, M. Skin as a potential organ for ectopic monoclonal antibody production. J Invest Dermatol 118, 288, 2002.

24. Shaw, J.A., Delday, M.I., Hart, A.W., Docherty, H.M., Maltin, C.A. and Docherty, K. Secretion of bioactive human insulin following plasmid-mediated gene transfer to non- neuroendocrine cell lines, primary cultures and rat skeletal muscle in vivo. J Endocrinol 172, 653, 2002. 
25. Green, H., Rheinwald, J.G. and Sun, T.T. Properties of an epithelial cell type in culture: the epidermal keratinocyte and its dependence on products of the fibroblast. Prog Clin Biol Res 17, 493, 1977.

26. Andreadis, S.T., Hamoen, K.E., Yarmush, M.L. and Morgan, J.R. Keratinocyte growth factor induces hyperproliferation and delays differentiation in a skin equivalent model system. Faseb J 15, 898, 2001.

27. Geer, D.J., Swartz, D.D. and Andreadis, S.T. Fibrin promotes migration in a three- dimensional in vitro model of wound regeneration. Tissue Eng 8, 787, 2002.

28. Geer, D.J., Swartz, D.D. and Andreadis, S.T. In vivo model of wound healing based on transplanted tissue-engineered skin. Tissue Eng 10, 1006, 2004.

29. Bajaj, B.G., Lei, P. and Andreadis, S.T. Efficient gene transfer to human epidermal keratinocytes on fibronectin: in vitro evidence for transduction of epidermal stem cells. Mol Ther 11, 969, 2005.

30. Ponec, M., Weerheim, A., Kempenaar, J., Mulder, A., Gooris, G.S., Bouwstra, J. and Mommaas, A.M. The formation of competent barrier lipids in reconstructed human epidermis requires

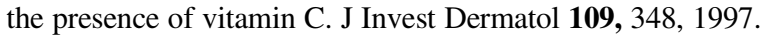

31. Pearton, D.J., Nirunsuksiri, W., Rehemtulla, A., Lewis, S.P., Presland, R.B. and Dale, B.A. Proprotein convertase expression and localization in epidermis: evidence for multiple roles and substrates. Exp Dermatol 10, 193, 2001.

32. Bajaj, B., Lei, P. and Andreadis, S.T. High efficiencies of gene transfer with immobilized recombinant retrovirus: kinetics and optimization. Biotechnol Prog 17, 587, 2001.

33. Lei, P., Bajaj, B. and Andreadis, S.T. Retrovirus-associated heparan sulfate mediates immobilization and gene transfer on recombinant fibronectin. J Virol 76, 8722, 2002.

34. Vaughan, F.L., Kass, L.L. and Uzman, J.A. Requirement of hydrocortisone and insulin for extended proliferation and passage of rat keratinocytes. In Vitro 17, 941, 1981.

35. Boyce, S.T. and Ham, R.G. Calcium-regulated differentiation of normal human epidermal keratinocytes in chemically defined clonal culture and serum-free serial culture. $\underline{\mathrm{J} \text { Invest }}$ Dermatol 81, 33s, 1983.

36. Burke, G.T., Hu, S.Q., Ohta, N., Schwartz, G.P., Zong, L. and Katsoyannis, P.G. Superactive insulins. Biochem Biophys $\underline{\text { Res Commun 173, 982, } 1990 .}$

37. Schwartz, G.P., Burke, G.T. and Katsoyannis, P.G. A superactive insulin: [B10- aspartic acid]insulin(human). Proc Natl Acad Sci USA 84, 6408, 1987.

38. Binley, J.M., Sanders, R.W., Master, A., Cayanan, C.S., Wiley, C.L., Schiffner, L., Travis, B., Kuhmann, S., Burton, D.R., $\mathrm{Hu}$, S.L., Olson, W.C. and Moore, J.P. Enhancing the proteolytic maturation of human immunodeficiency virus type 1 envelope glycoproteins. J Virol 76, 2606, 2002.

39. Mackenzie, I.C. Retroviral transduction of murine epidermal stem cells demonstrates clonal units of epidermal structure. J Invest Dermatol 109, 377, 1997.

40. Yanagita, M., Nakayama, K. and Takeuchi, T. Processing of mutated proinsulin with tetrabasic cleavage sites to bioactive insulin in the non-endocrine cell line, COS-7. FEBS Lett 311, 55, 1992.

41. Hunt, S.M., Tait, A.S., Gray, P.P. and Sleigh, M.J. Processing of mutated human proinsulin to mature insulin in the nonendocrine cell line, CHO. Cytotechnology 21, 279, 1996.
42. Yamasaki, K., Sasaki, T., Nemoto, M., Eto, Y. and Tajima, N. Differentiation-induced insulin secretion from nonendocrine cells with engineered human proinsulin cDNA. Biochem Biophys Res Commun 265, 361, 1999.

43. Martinenghi, S., Cusella De Angelis, G., Biressi, S., Amadio, S., Bifari, F., Roncarolo, M.G., Bordignon, C. and Falqui, L. Human insulin production and amelioration of diabetes in mice by electrotransfer-enhanced plasmid DNA gene transfer to the skeletal muscle. Gene Ther 9, 1429, 2002.

44. Hay, C.W. and Docherty, K. Enhanced expression of a furincleavable proinsulin. J Mol Endocrinol 31, 597, 2003.

45. Molloy, S.S., Bresnahan, P.A., Leppla, S.H., Klimpel, K.R. and Thomas, G. Human furin is a calcium-dependent serine endoprotease that recognizes the sequence Arg-X-X-Arg and efficiently cleaves anthrax toxin protective antigen. $\underline{\mathrm{J} \text { Biol }}$ Chem 267, 16396, 1992.

46. Min, C.Y., Qiao, Z.S. and Feng, Y.M. Unfolding of human proinsulin. Intermediates and possible role of its C-peptide in folding/unfolding. Eur J Biochem 271, 1737, 2004.

47. Qiao, Z.S., Min, C.Y., Hua, Q.X., Weiss, M.A. and Feng, Y.M. In vitro refolding of human proinsulin. Kinetic intermediates, putative disulfide-forming pathway folding initiation site, and potential role of C-peptide in folding process. $\mathrm{J}$ Biol Chem 278, 17800, 2003.

48. Chen, L.M., Yang, X.W. and Tang, J.G. Acidic residues on the $\mathrm{N}$-terminus of proinsulin C-peptide are important for the folding of insulin precursor. J Biochem (Tokyo) 131, 855, 2002.

49. Groskreutz, D.J., Sliwkowski, M.X. and Gorman, C.M. Genetically engineered proinsulin constitutively processed and secreted as mature, active insulin. J Biol Chem 269, 6241, 1994.

50. Fiorina, P., Folli, F., Bertuzzi, F., Maffi, P., Finzi, G., Venturini, M., Socci, C., Davalli, A., Orsenigo, E., Monti, L., Falqui, L., Uccella, S., La Rosa, S., Usellini, L., Properzi, G., Di Carlo, V., Del Maschio, A., Capella, C. and Secchi, A. Long-term beneficial effect of islet transplantation on diabetic macro-/microangiopathy in type 1 diabetic kidney-transplanted patients. Diabetes Care 26, 1129, 2003.

51. Fiorina, P., Folli, F., Maffi, P., Placidi, C., Venturini, M., Finzi, G., Bertuzzi, F., Davalli, A., D’Angelo, A., Socci, C., Gremizzi, C., Orsenigo, E., La Rosa, S., Ponzoni, M., Cardillo, M., Scalamogna, M., Del Maschio, A., Capella, C., Di Carlo, V. and Secchi, A. Islet transplantation improves vascular diabetic complications in patients with diabetes who underwent kidney transplantation: a comparison between kidney-pancreas and kidney-alone transplantation. Transplantation 75, 1296, 2003.

52. Melles, E., Bergman, T., Alvelius, G., Jonsson, A., Ekberg, K., Wahren, J. and Jornvall, H. Proinsulin C-peptide and its Cterminal pentapeptide: degradation in human serum and Schiff base formation with subsequent $\mathrm{CO} 2$ incorporation. Cell Mol Life Sci 60, 1019, 2003.

53. Fredriksson, A., Ekberg, K., Ingvar, M., Johansson, B.L., Wahren, J. and Stone- Elander, S. In vivo biodistribution and pharmacokinetics of (18)F-labeled human C-peptide: evaluation in monkeys using positron emission tomography. Life Sci 71, 1361, 2002.

54. Docherty, K. Gene therapy for diabetes mellitus. Clin Sci (Lond) 92, 321, 1997.

55. Riu, E., Mas, A., Ferre, T., Pujol, A., Gros, L., Otaegui, P., Montoliu, L. and Bosch, F. Counteraction of type 1 diabetic 
alterations by engineering skeletal muscle to produce insulin: insights from transgenic mice. Diabetes 51, 704, 2002.

56. Thule, P.M., Liu, J. and Phillips, L.S. Glucose regulated production of human insulin in rat hepatocytes. Gene Ther 7, 205, 2000.

57. Baron, U., Gossen, M. and Bujard, H. Tetracycline-controlled transcription in eukaryotes: novel transactivators with graded transactivation potential. Nucleic Acids Res 25, 2723, 1997.

58. Baron, U., Schnappinger, D., Helbl, V., Gossen, M., Hillen, W. and Bujard, H. Generation of conditional mutants in zhigher eukaryotes by switching between the expression of two genes [see comments]. Proc Natl Acad Sci USA 96, 1013, 1999.

Address reprint requests to: Stelios T. Andreadis Bioengineering Laboratory 908 Furnas Hall

Department of Chemical and Biological Engineering University at Buffalo, The State University of New York Amherst, NY 14260

E-mail: sandread@eng.buffalo.edu 

This article has been cited by:

1. Jun Tian, Pedro Lei, Suzanne G Laychock, Stelios T Andreadis. 2008. Regulated Insulin Delivery From Human Epidermal Cells Reverses Hyperglycemia. Molecular Therapy 16:6, 1146-1153. [CrossRef] 